\title{
Dampak Usia Pertama Pemberian Makanan Pendamping ASI Terhadap Status Gizi Bayi Usia 8-12 Bulan di Kecamatan Seberang Ulu I Palembang
}

\author{
Eka Intan Fitriana*, Julius Anzar*, HM. Nazir HZ*, Theodorus** \\ *Departemen Ilmu Kesehatan Anak Fakultas Kedokteran Universitas Sriwijaya/ RS. Dr. Moh. Hoesin \\ Palembang. ${ }^{* *}$ Unit Penelitian Kedokteran Kesehatan Fakultas Kedokteran UNSRI
}

\begin{abstract}
Latar belakang. Pemberian makanan pendamping ASI (MPASI) dini sebelum usia enam bulan akan menyebabkan bayi rentan mengalami penyakit infeksi dan alergi, sehingga dapat mengakibatkan malnutrisi dan gangguan pertumbuhan.

Tujuan. Menilai hubungan antara usia pertama pemberian MPASI terhadap status gizi bayi usia 8-12 bulan.

Metode. Penelitian kasus-kontrol dilakukan pada bulan 1 Februari-30 April 2012 di Puskesmas dan Posyandu di Kecamatan Seberang Ulu I Palembang. Sampel didapatkan secara consecutive sampling, dan dikelompokkan sebagai kelompok kasus dengan gizi kurang dan kelompok kontrol dengan gizi baik yang memenuhi kriteria inklusi. Semua subjek dilakukan penelusuran retrospektif mengenai usia pertamakali diberikan MPASI.

Hasil. Telah diteliti 240 subyek terdiri dari 80 subyek dengan gizi kurang dan 160 subyek dengan gizi baik. Hasil analisis chi-square dalam mencari hubungan antara usia pertama pemberian MPASI terhadap status gizi menunjukkan OR 1,42 dengan 95\% CI antara 0,8-2,4 ( $\mathrm{p}=0,2)$.

Kesimpulan. Pemberian MPASI dini tidak berhubungan dengan status gizi pada usia 8-12 bulan.

Sari Pediatri 2013;15(4):249-53.
\end{abstract}

Kata kunci: MPASI, gizi kurang, gizi baik, studi kasus kontrol.

\footnotetext{
Alamat korespondensi:

Dr. Julius Anzar, Sp.A. Departemen Ilmu Kesehatan Anak Fakultas Kedokteran Universitas Sriwijaya RS. Dr. Mohammad Hoesin, Palembang. Jl. Jendral Sudirman KM 3,5. Telp. (0711) 372832, (0711) 321635. E-mail: julius_anzar@idai.or.id
}

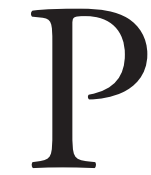
eriode emas dalam dua tahun pertama kehidupan anak dapat tercapai optimal apabila ditunjang dengan asupan nutrisi tepat sejak lahir. ${ }^{1}$ Air susu ibu (ASI) sebagai satusatunya nutrisi bayi sampai usia enam bulan dianggap sangat berperan penting untuk tumbuh kembang 
anak, ${ }^{2,3}$ sehingga rekomendasi dari pemerintah, bahkan kebijakan WHO mengenai hal ini telah ditetapkan dan dipublikasikan ke seluruh dunia. Pengukuran antropometri secara berkala dapat memantau pertumbuhan anak sehingga dapat menilai status gizi, mencegah dan mendeteksi adanya gangguan pertumbuhan (growth faltering). ${ }^{4}$

Pada kenyataannya, praktek pemberian MPASI dini sebelum usia enam bulan masih banyak dilakukan di negara berkembang seperti Indonesia. Hal ini akan berdampak terhadap kejadian infeksi yang tinggi, seperti diare, infeksi saluran napas, alergi, hingga gangguan pertumbuhan. ${ }^{5,6}$ Asupan nutrisi yang tidak tepat juga akan menyebabkan anak mengalami malnutrisi yang akhirnya meningkatkan angka morbiditas dan mortalitas. ${ }^{7}$ Angka kemiskinan yang masih tinggi memengaruhi daya beli masyarakat yang rendah sehingga kualitas, kuantitas dan higien MPASI yang diberikan tidak terjamin. Berbeda halnya di negara maju, daya beli masyarakat tinggi dan mengerti cara penyajian MPASI yang baik, sehingga kualitas dan kuantitas MPASI dapat terjamin, ${ }^{8}$ maka amat wajar apabila didapatkan status gizi saat berusia dua belas bulan dalam batas baik.

Penelitian sebelumnya di Indonesia lebih banyak menilai pertambahan berat badan bayi antara yang mendapat ASI eksklusif dan yang mendapatkan MPASI dini. ${ }^{9} 10$ Pada penelitian ini ditemukan bahwa berat dan panjang badan bayi yang diukur saat pemeriksaan dapat dihitung sebagai status gizi. Tujuan penelitian ini untuk menilai hubungan antara usia pertama pemberian MPASI terhadap status gizi bayi usia 8-12 bulan di Kecamatan Seberang Ulu I Kota Palembang, Sumatera Selatan.

\section{Metode}

Penelitian kasus-kontrol yang dilakukan pada 1 Februari - 30 April 2012 di Puskesmas dan Posyandu yang berada dalam wilayah kerja Kecamatan Seberang Ulu I, Palembang. Pengambilan sampel dilakukan secara consecutive sampling, pada bayi usia 8-12 bulan yang datang untuk berobat/imunisasi yang memenuhi kriteria inklusi.

Kriteria inklusi pada kelompok kasus adalah bayi dengan riwayat kelahiran spontan pervaginan, aterm (37-42 minggu), tidak asfiksia, tidak ada faktor risiko ibu maupun janin, berat badan lahir 2500-4000 g, tidak ada kontraindikasi menyusui, membawa kartu menuju sehat (KMS) saat kunjungan, dan berstatus gizi kurang. Kriteria inklusi untuk kelompok kontrol sama dengan kelompok kasus, kecuali dengan status gizi baik. Teknik matching dilakukan berdasarkan usia, jenis kelamin, dan berat badan lahir. Kriteria eksklusi adalah infeksi kronis, penyakit kronis, kelainan kongenital, dan defek neurologis. Penelitian ini disetujui oleh Komisi Etik Penelitian Kesehatan FK-UNSRI/RSMH dan semua orang tua subjek menandatangani formulir informed consent.

Seluruh subyek yang memenuhi kriteria inklusi dilakukan pengukuran berat badan (Gea Medica baby scale) dan panjang badan menggunakan pengukur panjang badan kayu dengan akurasi pengukuran hingga $0,1 \mathrm{~cm}$. Interpretasi status gizi menggunakan kurva $z$ score WHO 2006 berdasarkan berat badan menurut panjang badan, sesuai dengan jenis kelamin.

Data mengenai berat dan panjang badan lahir, usia gestasi didapatkan dari kartu menuju sehat (KMS) dan wawancara dengan ibu, kemudian dilakukan penelusuran retrospektif tentang riwayat pertama kali pemberian dan jenis MPASI. Perkiraan besar sampel dihitung berdasarkan data tahun 2001, didapatkan prevalensi pemberian MPASI dini di Indonesia 47\%. Dari data ini kemudian dicocokkan pada tabel for case-control study dan dipilih perbandingan 1:2 dengan OR 2,5 atas pertimbangan pengambilan sampel yang memungkinkan dan tingkat kemaknaan, sehingga didapatkan jumlah kelompok kasus 80 orang dan jumlah kelompok kontrol 160 orang. ${ }^{11}$ Analisis data menggunakan chi square test dengan perangkat lunak SPSS versi 16. Batasan operasional pemberian MPASI dini yaitu pemberian MPASI mulai usia kurang dari enam bulan, sebelumnya diberikan ASI saja dan masih memberikan ASI hingga saat penelitian dilakukan, sedangkan yang dimaksud dengan pemberian MPASI tepat waktu adalah pemberian MPASI mulai usia 6-7 bulan dengan ASI eksklusif sebelumnya dan masih memberikan ASI saat penelitian dilakukan.

\section{Hasil}

Pada periode penelitian didapatkan 240 subyek, terdiri dari 80 subyek dengan gizi kurang dan 160 subyek dengan gizi baik. Karakteristik subyek penelitian tertera pada Tabel 1.

Pada kondisi sosiodemografi ibu, didapatkan usia 
ibu dalam kisaran 15-45 tahun dengan rerata 28,7 (SB 5,33) pada kelompok kasus dan 28,5 (SB 5,66) kelompok kontrol. Paling banyak dijumpai pendidikan SMA/SMEA/SMK (38,75\% pada kelompok kasus dan $48,1 \%$ kelompok kontrol) dan ibu yang tidak bekerja (91,25\% pada kelompok kasus dan 92,5\% kelompok kontrol).

Gambar 1 menunjukkan distribusi jumlah bayi yang mulai diberikan MPASI menurut usia pada kedua kelompok. Didapatkan 41 (51,25\%) subyek yang mendapatkan MPASI dini pada kelompok kasus dan 68 (42,5\%) subyek kelompok kontrol. Sedangkan pada pemberian MPASI tepat waktu, didapatkan $39(48,75 \%)$ subyek pada kelompok kasus dan 92 (57,5\%) subyek kelompok kontrol.

Jenis MPASI dini yang diberikan pertama kali cukup beragam. Jumlah bayi yang diberikan MPASI dini 109 subyek, dengan masing-masing subyek dapat diberikan lebih dari satu jenis MPASI. Sembilanpuluh tiga (85,32\%) subyek yang mendapatkan susu formula, $80(73,4 \%)$ yang diberikan susu kotak, 53 (48,6\%) diberikan biskuit, 48 (44\%) diberikan pisang, 46 (42,2\%) mendapatkan bubur buatan sendiri, dan lima subyek (4,6\%) yang diberikan air tajin sebagai MPASI pertama. Secara keseluruhan, rerata usia pemberian MPASI dini adalah 3,07 (SB 1,39) dengan median 3,00.

Tabel 2 menunjukkan hubungan antara pemberian MPASI dan status gizi. Terdapat $41(51,25 \%)$ dan 68 (42,5\%) subyek dengan pemberian MPASI dini mengalami gizi kurang dan gizi baik, sementara 39 $(48,75 \%)$ dan $92(57,5 \%)$ subyek dengan pemberian MPASI tepat mengalami gizi kurang dan gizi baik. Hasil menunjukkan tidak ada hubungan antara pemberian MPASI dan status gizi. Pada analisis data didapatkan Odds ratio (OR) 1,42 dengan 95\% CI antara 0,8 dan 2,4 .

Tabel 1. Karakteristik dasar subyek penelitian $(\mathrm{n}=240)$

\begin{tabular}{|c|c|c|c|c|c|c|}
\hline \multirow[t]{2}{*}{ Karakterisktik } & \multicolumn{2}{|l|}{ Gizi kurang } & \multicolumn{2}{|l|}{ Gizi baik } & \multicolumn{2}{|c|}{ Jumlah } \\
\hline & $\mathrm{n}$ & $\%$ & $\mathrm{n}$ & $\%$ & $\mathrm{n}$ & $\%$ \\
\hline \multicolumn{7}{|l|}{ Jenis kelamin } \\
\hline Laki-laki & 37 & 46,25 & 74 & 46,25 & 111 & 46,2 \\
\hline Perempuan & 43 & 53,75 & 86 & 53,75 & 129 & 53,8 \\
\hline \multicolumn{7}{|l|}{ Usia, (bulan) } \\
\hline 8 & 11 & 13,75 & 22 & 13,75 & 33 & 13,8 \\
\hline 9 & 20 & 25 & 40 & 25 & 60 & 24,9 \\
\hline 10 & 13 & 16,25 & 26 & 16,25 & 39 & 16,2 \\
\hline 11 & 14 & 17,5 & 28 & 17,5 & 42 & 17,4 \\
\hline 12 & 22 & 27,5 & 44 & 27,5 & 66 & 27,7 \\
\hline Rerata usia (bulan) & $8,9(\mathrm{SB} 2,25)$ & & $8,9(\mathrm{SB} 2,25)$ & & & \\
\hline \multicolumn{7}{|l|}{ Berat badan lahir (gram) } \\
\hline $2500-<3000$ & 36 & 45 & 72 & 45 & 108 & 45 \\
\hline $3000-<3500$ & 33 & 41,25 & 66 & 41,25 & 99 & 41,3 \\
\hline $3500-<4000$ & 11 & 13,75 & 22 & 13,75 & 33 & 13,8 \\
\hline Rerata (berat badan) & 2994,1 (SB 373,22) & & 2994,1 (SB 373,22) & & & \\
\hline \multicolumn{7}{|l|}{ Panjang badan lahir $(\mathrm{cm})$} \\
\hline $45-47$ & 30 & 37,5 & 32 & 20 & 64 & 25,8 \\
\hline $48-50$ & 48 & 60 & 120 & 75 & 168 & 70 \\
\hline $51-53$ & 2 & 2,5 & 8 & 5 & 10 & 4,2 \\
\hline Rerata (panjang badan) & $48,2(\mathrm{SB} 1,54)$ & & $48,6(\mathrm{SB} 1,34)$ & & & \\
\hline \multicolumn{7}{|l|}{ Usia gestasi (minggu) } \\
\hline $37-42$ & 78 & 97,5 & 153 & 95,7 & 231 & 96,2 \\
\hline $40-42$ & 2 & 2,5 & 7 & 4,3 & 9 & 3,8 \\
\hline Rerata (usia gestasi) & $37,3(\mathrm{SB} 0,63)$ & & 37,3 (SB 0,73) & & & \\
\hline Jumlah & 80 & 100 & 160 & 100 & 240 & 100 \\
\hline
\end{tabular}




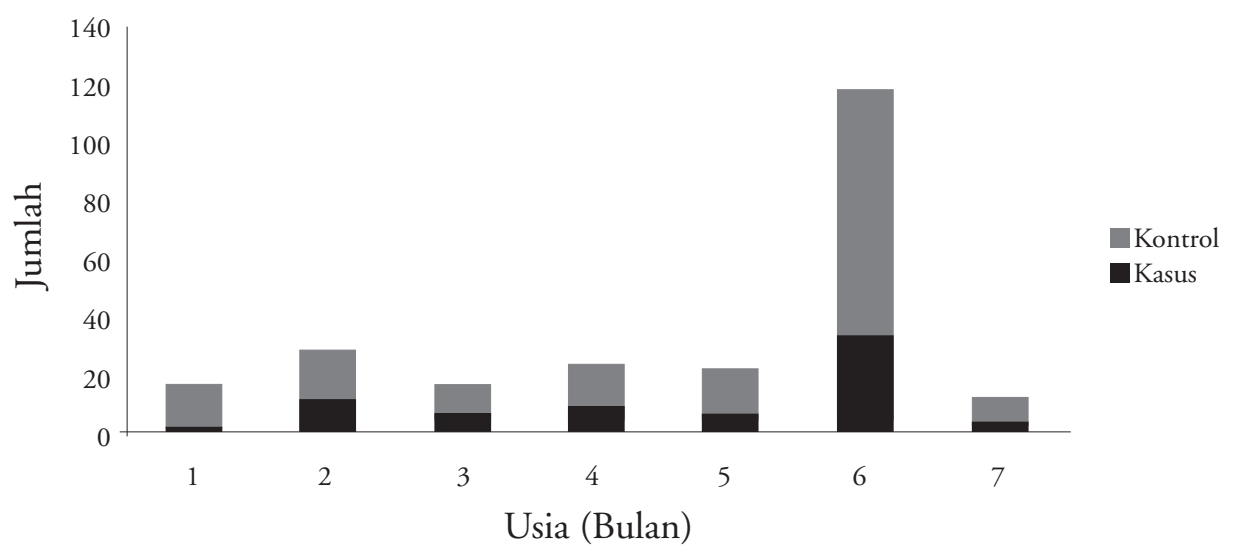

Gambar 1. Distribusi usia pertama pemberian MPASI ( $\mathrm{n}=240)$

Tabel 2. Hubungan antara usia pertama pemberian MPASI dan status gizi $(n=240)$

\begin{tabular}{lccccc}
\hline \multirow{2}{*}{ MPASI } & \multicolumn{2}{c}{ Gizi kurang } & \multicolumn{2}{c}{ Gizi baik } & OR \\
\cline { 2 - 5 } & $\mathrm{N}$ & $\%$ & $\mathrm{n}$ & $\%$ & $(95 \% \mathrm{CI})$ \\
\hline Dini & 41 & 51,25 & 68 & 42,5 & 1,42 \\
Tepat & 39 & 48,75 & 92 & 57,5 & $(0,8-2,4)$ \\
Jumlah & 80 & 100 & 160 & 100 & \\
\hline
\end{tabular}

Chi-square test; $p=0,2$

\section{Pembahasan}

Penelitian kasus-kontrol berbeda dengan penelitian yang dilakukan sebelumnya yang lebih banyak bersifat penelitian longitudinal dengan pemantauan berkala pada berat badan bayi usia $0-6$ bulan antara bayi yang mendapatkan ASI eksklusif dan yang mendapatkan MPASI dini.

Tidak didapatkan hubungan antara usia pertama pemberian MPASI dan status gizi bayi (OR: 1,42 (95\% CI 0,8-2,5; $\mathrm{p}=0,3)$. Menurut literatur, terdapat beberapa faktor dari MPASI yang memengaruhi status gizi bayi, seperti kualitas, kuantitas, higiene, dan jadwal/waktu pemberian MPASI. Apabila faktor tersebut baik, maka status gizi bayi akan baik. Penelitian yang pernah dilakukan di Indonesia, ditunjukkan perbedaan pada rata-rata pertambahan berat badan per bulan sejak bayi lahir sampai usia empat bulan antara kedua kelompok yang mendapatkan ASI eksklusif dan kelompok yang mendapatkan MPASI sebelum usia empat bulan, ${ }^{9,10}$ Namun, dua penelitian tersebut tidak menilai pertambahan panjang badan dan status gizi, sehingga hasilnya tidak bisa dijadikan bahan acuan pada penelitian kami.

Terdapat satu penelitian mengidentifikasi 22 penelitian terpisah dengan melakukan evaluasi terhadap sebelas penelitian yang dilakukan di negara berkembang dan sisanya dilakukan di negara maju. ${ }^{12}$ Dua penelitian dari penelitian tersebut membandingkan pertambahan berat dan panjang badan pada usia 4-6 bulan dan 6-12 bulan dengan pengukuran perbulan berdasarkan $\mathrm{BB} / \mathrm{U}, \mathrm{PB} / \mathrm{U}, \mathrm{BB} / \mathrm{PB}$ menurut kurva $z$ score WHO pada kelompok ASI eksklusif hingga usia enam bulan dan kelompok yang diberikan MPASI dalam kisaran usia 4-6 bulan dengan tetap melanjutkan ASI. Hasil penelitian menunjukkan tidak didapatkan perbedaan antara kedua kelompok. Hasil yang sama didapatkan pada penelitian observasional di empat negara berkembang (Peru, Filipina, Sinegal, dan Iran) dan Belarus. ${ }^{12-14}$

Walaupun tidak dijumpai perbedaan bermakna terhadap status gizi antara bayi yang mendapatkan ASI eksklusif dan MPASI dini terhadap status gizi pada penelitian sebelumnya, rekomendasi WHO mengenai pemberian ASI eksklusif hingga usia enam bulan di negara maju tetap diteruskan dengan pertimbangan 
bahwa bayi dengan ASI eksklusif akan memiliki tingkat kecerdasan dan emosional yang lebih baik, selain memiliki berat dan panjang badan proporsional. Sebagian masyarakat di negara berkembang masih beranggapan bahwa anak gemuk tampak lebih sehat dengan pemberian MPASI dini, sehingga masih diperlukan upaya penggalakan ASI eksklusif secara berkesinambungan demi terciptanya tunas-tunas harapan bangsa yang berkualitas.

\section{Kesimpulan}

Status gizi pada usia 8-12 bulan tidak berhubungan dengan usia pertama pemberian MPASI. Hal tersebut dapat disebabkan karena adanya faktor-faktor lain yang memengaruhi status gizi seperti kualitas, kuantitas dan higienitas MPASI. Faktor-faktor tersebut dapat dijadikan variabel bila diperlukan untuk penelitian mendatang.

\section{Daftar pustaka}

1. Depkes R.I. Makanan pendamping air susu ibu (MPASI). Jakarta: Direktorat Gizi Masyarakat, Direktorat Jendral Kesehatan Masyarakat; 2000.

2. Brown KH, Dewey K., Allen L. Breast-feeding and complementary feeding. Complementary feeding of young children in developing countries: A review of curent scientific knowledge. Geneva: World Health Organization;1998.h.27-33.

3. Peraturan Pemerintah RI. Peraturan Pemerintah RI nomor 33 tahun 2012 tentang pemberian air susu ibu eksklusif. (Diakses 4 November 2013). Didapat dari: http://www.litbang.depkes.go.id/sites/download/regulasil pp/PP_ASI_Eksklusif2012.pdf.
4. Cogill B. Anthropometry indicators measurement guide. Washington DC: Food and nutrition technical assisstance; 2001.

5. Brown KH, Dewey K., Allen L. Breast-feeding and Complementary feeding. Complementary feeding of young children in developing countries: A review of curent scientific knowledge. Geneva: World Health Organization;1998.h.15-7.

6. Dina. Ibu berikan asi eksklusif baru dua persen. 2005 (Diakses 4 November 2011). Didapat dari: http://www. depkes.go.id/.

7. Dietz WH. Breastfeeding may help prevent childhood overweight. JAMA 2000;285:2506-7.

8. Dewey KG, Heinig MJ, Nommsen LA, Person JM, Lonnerdal B. Growth and breasfed and formula-fed infants from 0-18 months: the darling study. Pediatrics 1992;89:1035-41.

9. Saputra DK, Carolina, Riko R. Duration of breastfeeding has a positive effect on infant weight gain. Universa Medicina 2010;29:21-6.

10. Widodo Y, Rianto BU, Zuleha. Pertumbuhan bayi usia 0-4 bulan yang mendapat ASI eksklusif dan makanan pendamping ASI. Sains Kesehatan 2005;18:427-41.

11. Brian LS. Sample sizes for case-control studies. Pharmacoepidemiology. Edisi ke-3. Philladelphia:Wiley Andsons; 2000.

12. Kramer MS, Kakuma R. The optimal duration of exclusive breastfeeding. A systematic review. Adv Exp Biol 2004;554:63-77.

13. Kramer MS, Chalmers B, Hodnett ED, Sevkovskaya Z, Dzikovich I, Shapiro S, dkk. Breastfeeding and infant growth: biology or bias? Pediatric Res 2000;47:151A.

14. Simondon KB, Simondon F. Age at introduction complementary food and physical growth from 2 to 9 month in rural Senegal. Euro J Clin Nutr 1997;51:7037. 